\title{
Educação Popular e questões de poder
}

\author{
Popular Education and power issues
}

\section{Educación Popular y cuestiones de poder}

Sonia Fleury (a)

A Constituição previu um conjunto de inovações que permitiram a expansão da esfera pública democrática e a garantia de direitos sociais. Inspirou-se nos princípios da justiça social e primado dos direitos da social-democracia, mas inovou ao introduzir um desenho institucional descentralizado e participativo. A participação ficou assegurada por meio de mecanismos de negociação e pactuação entre os entes federativos, como as comissões, mecanismos de controle social, como os conselhos, e mecanismos de mobilização, como as conferências.

Essas inovações deram uma nova dinâmica aos desafios de um federalismo colaborativo que careceu de regulação das competências comuns e concorrentes, bem como introduziu mecanismos de democracia deliberativa e cogestão. O êxito de ambos depende de um constante processo de mobilização da sociedade civil, capaz de formar a vontade política, ampliar a agenda pública e também legitimar o exercício do poder.

A participação em políticas públicas pressupõe formas de interação entre Estado e sociedade que sejam capazes de assegurar a ambos, tanto sua necessária autonomia como a eficácia na inserção dos projetos governamentais ou societários na agenda pública. A perda de autonomia representaria a possibilidade de apropriação patrimonial dos órgãos públicos por interesses de grupos particulares ou bem como a cooptação dos últimos pelo poder estatal. Ambos os casos comprometem a democracia, corrompem o interesse público e a eficácia das políticas, além de alienar os sujeitos de suas bases e interesses.

Já o virtuosismo dos arranjos institucionais participativos possibilitaria o reconhecimento da diversidade de atores e interesses, a transação dos conflitos, o intercâmbio de informações e a construção de consensos que dariam maior enraizamento e legitimidade às políticas públicas. Em todos os seus níveis e instâncias, tratar-se-ia de um processo de interpelação dos sujeitos políticos, que permitiria o confronto de identidades em interação, bem como sua transformação. Trata-se, portanto, de um verdadeiro projeto educacional que visa a transformações de estruturas institucionais estatais e de identidades e alianças societárias.

Em seu artigo, Stotz se propõe a entender os desafios do controle social a partir de sua vivência no movimento de Educação Popular em Saúde, fundamentada em leituras das correntes marxistas e da pedagogia e teologia da libertação. $O$ autor conclui que a experiência de participação política anterior à conquista do poder sob a democracia burguesa é fundamental para o "exercício da mais 'ampla' e ilimitada democracia".

\footnotetext{
(a) Escola Brasileira de Administração Pública da Fundação Getúlio Vargas. Praia de Botafogo, 190/518, Botafogo. Rio de Janeiro, RJ, Brasil. 3799-5783. www.peep. ebape.fgv.br
} 
A busca da hegemonia insinua-se, mas não se realiza nesse artigo, restringe-se ao conceito leninista, pois falta-Ihe a concepção gramsciana do Estado Ampliado, onde se dá a disputa pela hegemonia pelas classes dominadas. A reafirmação categórica das limitações da democracia burguesa, malgrado a importância de nela participarem as classes dominadas, não deixa claro como evitar as armadilhas classitas do clientelismo e patrimonialismo, inerentes ao presidencialismo de coalizão.

Já com relação aos mecanismos de participação, o autor identifica o processo das conferências como o lugar do instituinte, enquanto os demais espaços, como os conselhos, são considerados estatalmente controlados. Coloca a pergunta sobre a possibilidade, na atual conjuntura, de conferências populares e democráticas, invertendo o modelo atual em que o governo convoca e cria uma pauta de discussões.

A dialética entre participação, reconhecimento e redistribuição está na essência desse debate sobre poder compartilhado. Nossa tese é que a dissociação entre reconhecimento e redistribuição pode ter efeitos perversos na sociabilidade. Por um lado, o reconhecimento, sem redistribuição gera novos sujeitos, mas não uma nova sociedade, pois as relações de subordinação material ficam inalteradas. Nesse caso, o reconhecimento tende a ser apenas tolerância, o que está aquém das exigências materiais de uma inclusão autônoma.

Por outro lado, a redistribuição sem reconhecimento tende a ser uma nova forma de tutela política, reproduzindo relações de dominação, como o clientelismo e populismo, por meio de políticas focalizadas e com distribuição condicionada. Nesse caso, a inclusão tutelada é antagônica à cidadania, entendida como processo de subjetivação.

A constituição do sujeito deve ser vista dentro da perspectiva de uma ação que afirma sua liberdade e consciência, dentro de um enquadramento que não foi por ele escolhido. É no interior dessa tensão entre determinação social e afirmação da liberdade individual e grupal que buscamos encontrar o lugar da constituição dos sujeitos.

A subjetividade é vivida como alienação na aceitação da dominação e opressão ou pode implicar em uma reapropriação criativa na qual o indivíduo produz a sua singularidade em um contexto relacional dado. Tais tensões não se restringem ao plano de luta da economia política, mas dizem também respeito ao campo da micropolítica, passando ao campo da economia subjetiva.

No nosso entender a expansão da esfera pública por meio da transformação das estruturas políticas, sociais e econômicas envolve um processo que inclui um triplo movimento de subjetivação, institucionalização e constitucionalização'.

A subjetivação diz respeito à constituição de sujeitos políticos, implicando na construção de identidades individuais e de grupo que rompem as identidades subordinadas e alienadas por meio de um processo de singularização e construção de uma estratégia de transformação social e ruptura com as relações percebidas como de opressão. A ruptura se dá na própria constituição dos sujeitos, porque ela põe em causa as estruturas da dominação.

A constitucionalização engloba as normas procedimentais e legais que asseguram o reconhecimento social dos novos sujeitos como incluídos na esfera pública, garantindo-lhes a reciprocidade com os demais membros da comunidade de cidadãos e o gozo dos direitos e deveres relacionados a esse status.

Se a subjetivação e a constitucionalização refletem e, ao mesmo tempo, alteram a correlação de forças e a distribuição social, torna-se necessária uma mudança compatível na institucionalidade estatal, que assegure o exercício dos direitos em uma condição de esfera pública ampliada. A institucionalização diz respeito aos processos de transformação das estruturas e dinâmicas institucionais, mormente às estatais, nas quais se plasmam essas novas relações de poder. Trata-se de inovar e inventar processos, metodologias, dinâmicas e estruturas que permitam e consolidem a expansão da cidadania e a inclusão social.

As formas inovadoras de ação coletiva requerem uma nova gramática política que se plasme em instituições e práticas renovadas, tanto em âmbito da sociedade quanto do Estado, e aparecem como uma estratégia original de inclusão social. Recusar essa dialética entre instituinte e instituído pode terminar por reduzir a revitalização da política ao experimentalismo localista. 


\section{Referência}

1. Fleury S. Salud y democracia en Brasil: valor publico y capital institucional en el sistema unico de salud. Salud Colect. 2007;3(1):147-57. 
